2n Beebe, S.: The Effect of Alcohol and Alcoholic Fluids upon the fixcretion of Uric Acid in Mun. Amer. Jour. of Physiol., $1004,12,13$.

Huldule and Poulton: The Effects of Want of Oxysen on the lespiration. Jour. of Physiol., 1908, 37, 390.

37 Lavoinier: Experiences sur la respiration des animaux et sur les changements qui arrivent a l'air en passant par leur jou

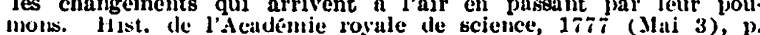
Imotis.

Seguin et Javoisier: Premier Memoire sur la respiration des unimutux. Histoire et llem. de l'Acad. des sciences, 1780, p. 566.

Seguin et lavoisier: Premier Memoire sur la transpiration des animaux. Mémoire de l'Acadénie des sciences, April 1f, 1700, 1). 001 .

seruin: Mémoire sur l'endonctrie. Anu. de chimic et de phosicue, $1791,0,293$

It Rermant et Reiset: Recherches chimiques sur la respiration des unimaux des diversess classes. Anu. de chimie et de physinue, 3ieme $x+r .01840,20,200$.

2 Muller, "W.: Deitribe zur Theorie der Rexpiration. Sitzungber.

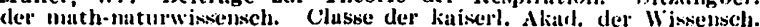
in Wien, $1858,33,90$.

2 I.usk, G.: The Elements of the Science of Nutrition, 1909, pl). $29-31$ regarding voit and Pfliker, J. 19 regarding Ludwir.

24 Maller, J.: II andbuch der Physiologie der Ilenschen, 1838, vol. 1, p. 334 .

Warner's Handwörterbuch der physiologie, 1844, rol. 2, p. 008

Meyer, 1.: Die Case des J3lutes. Zeitschr. f. rat. Meal., 1857, Fige, 8,250

Trans Experimentelle l'ntersuchungen liber die Transfusion, Transplantation oder Substitution des mlutes in theoretischer und pract ischer Bezichung. Virchow's Arch. f. path. Amut., 1863, 27 433.

Pfliger und Zuntz: Veber den Einfluss der Siluren auf die (iuse

des Blutes. Al'h. f. cl. ges. l'hysiol, J868, 1, 361.

ron Pettenkofer und Voit, (I.: Intersuchungen iber den stoffverbrauch des normalen Menschen. Zeitschr. f. Hiol., 1860, 2 458 (espxciully p. 536)

Loxsen, H. (in Voit's laboratory): Ueber den Einfluss der Zahle und Tiefe der Athembewegungen auf die Ausscheidung der lioh

ensilure durch die J.mngen. Weitschr. f. Miol., 1866, 2, 244.

Voit, C.: Ceber Fettlildung in Thierkörper. Zeitschr. f. Biol.

Jossen, H. (in Voit's laborntory): Bemerkungen zu ter Abhandlung von Dr. Eugen Berg tiber den Einfluss der Zahl und Tiefe der Athembewerungen auf die Ausscheidung der liohlen-

silure dirch the limge. Zeitschr. f. Biol., 1870, 6, 208.

roit, C.: Cober das Gaswechsel nach Durchschnejulung ier nerv vagi. Sitzungsber der künigl. bayerisch. Akud, der Wissensch.

* Salkowski: Beitrige zur Kenntniss der Leukilmie. Virchow's Arch. P. path. Anat., 1870, 50, 174.

Pettenkofer und Voit: Leber den Stoffverbrauch bei einem leukllmischen Manne. Zeitschr. f. Biol., 1808, 5, 318.

Senator, H.: Experimentelle Untersuchungen uber den Binflus von Respirations-stibrungen auf den Stoffwechsel. Virchow's

Arch. 1. path. Anat., 1868, 1, 42.

Yoit, C: Leber die Entwicklung der Lehre von der Quelle der Mfuskelkraft unl einiger Theile der Ernllhrung seit 25 Jahren. Zeitschr. f. Biol., 1870, 6, 305.

Pettenkofer, M., und Voit, C.: Veber die Zersetzungsvorginge im Thierköper bei Futterung mit Fleisch. Zeitschr. f. Biol. $1871,7,433$.

Hoppe-Sevler: Beitrikge zur Kenntniss der Constitution des Blutes. Medicinisch-chem. Untersuchungen, Berlin, 1866-1871, p. 133.

Takfes, A.: Beitrag zur Jehre von der Oxydution' im Orannis. mus. Zejtschr. f. physiol. Chem., 1878, 2, 372 (from HoppeSerler's laboratory).

Pfiuger, E.: Iteler die Oxydntionsprocessen im lebendigen Blute. Centralbl. f. d. med. Wissensch., 1867, 5, 321

Pfliger, f.: Die normalen Gasmengen des arterielen Blutes nnch verbesserten Methoden. Centralbl. f. d. med. Wissensch., 1867, 5,722

Zuntz (in Pfliger's laboratory): Zur Kenntniss des Stoffichech im Blute. Centralbl. f. d. med. Wissensch., 1867, 5, 801. Pfliger, F., und Zuntz: Ueber den Finfluss der Siiuren auf die Gase des Blutes. Arch. f. d. ges. Physiol., 1808, 1, 361. im arteriellen Blutstrom. Arch. f. d. ges. Phisiol., 1868, 274 (especially p. 279)

to Pfliger, F.: Ueber die Ursache der Athembewegungen sowio der Dyspnot und Apnot. Arch. f. d. ges. Physiol., 1868, 1, 61.

4 Voit. C.: Beschreibung gasformingen Ausscheidungen des Thierkirpers. Zejtschr. f. Biol. $1875,11,532$.

42 Pflikger, J.: Beitrilge zur Tehre von der Rexpirntion. Arch. f. d.

"Finkler (in Pflitger's laboratory): Ueber den Vinfluss der Strßmungsgeschwindigkeit und Menge des Blutes auf die thierische Verbrenmung. Arch. f. d. Les. Physiol., 1875, 10, 368.

Pfliger, E.: Ueber Temperatur und Stoffwechsel der Sllugethiere.

Arch. f. d. ges. Physiol., 1876, 12, 282.

Pftilger, F.: Ueber Wlirmeregulation bei Sllugethiere. Arch. $f$ d. ges. Physiol., 1876, 12, 333.

Pflitrer, F:: Ueber den Einfluss ier Athemmechanik auf den Stoffwechsel. Arch. f. d. ges. Physiol., 1877, 14. 1.

Finkle1, 1).: und Oertmann, E. (in P̈llicer's laboratory) : Teber den Einfluss der Athemmechanik auf den stoffwescshel. Aich. f. d. ges. Physiol., 1877, 14, 38.

Pfllger, E.: Die telenlogische Mechanik der lebendigen Natur. Arch. f. d. ges. Physiol., 1877, ]5, 57.

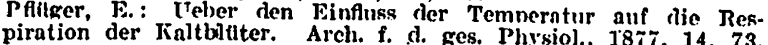
P'fliger, F.: Antwort auf die berichtigende "Bemerkumg des
IIerru Professor Dr. H. Senator. Arch. f. d. I'hysiol., 1877, 14, $\mathbf{4 5 0} 0$.

Pflliger, E.: Nachtrac zu Dr. G. Colosanti's in diesem Archive (J3d. 14. S. 02) enthaltenen Abhandlung. Arch. it. d. ges. (3d. 14. 5. 02) enthat

Physiol, 187, 14, 469. IIerrn prof. II. Senator in Berlill. Archiv f. d. ges. Physiol. $187 \pi, 14, \overline{0} 02$.

prliurer, Athembewerumben zu dem Stoffwechsel. Arch. f. d. ges. l'hvsiol. $1877,14,630$.

$187 \pi, 14,630$. ges. plisiol., 1878, 18, 381.

4 Ses. Physiol., 1878, 18, 381. tion. Areh. f. d. pes. Physiol., 1875, 10, 251.

tion. Areh. f. d. Les. Physiol., 1875, 10, 251. Stinzing, R. (in P'tliger's laboratory): intersuchungen meber d. gex. Physiol., 1878, 18, 388.

is Ludwig, Phisiol., 1878, 18, 388. Das Verhalten fer Gase welche mit dem Blute durch den reizbaren süugethiermuskel strömen. mit dem Blute durch den reizbaren süugethiermuskel stromen. Wissense h. Math.-phys. Classe, 1838, 20, 12.

see ensecially Pilizer. F. : Vber Wilme und Oxidation der leben. disen encially Piliger. F.: Dber Wime und Oxidation der leben. digen Materie. Arch. f. d. Kes. Physiol., 1878, 18, 247; and ges. Physiol., 1879, 19, 160.

\section{ROENTGENTHERAPY IN HYPERTROPHY OF THE THYMUS GLAND.*}

\author{
By Philip H. Cook, M.D., Worcester,
}

Rocntgenologist, Citll and Memorial JIospitals; Physician to Out-pafients, City Hospital, Worcester.

Is no line of recent medical research has greater interest been taken, nor more fruitful results obtained, than that pertaining to the ductless glands. Each of these organs by its separate action, and by its interrelation with others, has been shown to have effects upon the bodily economy which present a problem at once perplexing and fascinating to investigator and clinician alike. And some of the most interesting clinical questions centre about the thymus gland.

Anatomy and Development. In man the thymus develops as a paired organ from the ventral part of the third branchial cleft; at birth the organ lies behind the sternum, backward as far as the pericardium, reaching above somewhat higher than the jugular notch. Accessory lobes lying within the thyroid or closely united with it may develop from the fourth cleft. "The close association," says Noel Paton," "of such a structure with the original direct channel of the blood-flow to the body suggests the occurrence of some modification in the blood en route for the tissues." This statement should be borne in mind when discussing the clinical symptomatology of the gland.

It consists of two chief lobes, one on each side, and each subdivided into a number of small globules. Each lobule is surrounded by a fibrous capsule, and is densest at the periphery. The epithelial structure, of which the gland essentially consists, forms a branching network throughout the lobules, at some places concentrated into masses of cells, which degenerate into large, more or less circular bodies,- the so* Read before the Worcester District Medical Society, Nov. 10, 
called corpuscles of Hassall. They are invaded by polymorphonuclear leucocytes, and their protoplasm contains granules staining deeply with basic stains. The interstices of the epithelial groundwork are filled with lymphocyte-like cells, the nature of which is still under dispute, one school of writers asserting them to be true lymphocytes derived from outside, the others to be derived from the epithelial cells and hence really epithelial in nature. Upon this point depends, in large measure, the classification of the gland in its relation to the bodily economy, whether with the lymphatic apparatus, as was formerly supposed, or with the system of hormone producers. Without attempting to take sides in the controversy, it may be remarked that it is against these cells, that the Roentgentherapist in large measure directs his efforts, and that they react like other structures of known lymphatic character.

In man, as in most other animals, the thymus reaches its greatest size in relation to the body at the time of birth; thereafter it continues to grow, but at a reduced rate, growth ceasing only with the beginning of sexual maturity; it then atrophies, the essential tissue being replaced by fibrous tissue and fat, and is finally reduced to a mass of adipose tissue with a few islands of thymus remaining.

Plysiology. That the secretion of the organ is essential to the normal development of infancy and early childhood seems definitely proven. Klose and Vogt, ${ }^{2}$ by splitting the sternum, removed the thymus from 54 dogs. All the operated animals died in from three to seventeen months, after passing through certain definite stages. After a short latent period, characterized by ravenous appetite, they passed into a second stage of adiposity, in which they became heavier than their controls, with apathy and muscular weakness. Soon, however, the third stage of idiota thymica supervened, the animal becoming cachectic, clumsy, and stupid: A coma of several days followed, ending in death. The most important developmental variation in these thymectomized animals was found to lie in the small size of the skeleton and poverty of lime salts in the bones. The changes were those of osteoporosis and osteomalacia. In delayed ossification and diminished lime content they somewhat resembled rhachitic change. The experimenters ascribed these conditions to a nucleinic acid intoxication, normally neutralized by thymus secretion.

The experiments of Svehla, ${ }^{3}$ who by injection of watery thymus extract produced lowered blood pressure and eventual death in dogs, have been largely discounted by Popper ${ }^{4}$ and other later workers, so that the effect of hyperthymization must be considered from the experimental standpoint is still unknown:

The interrelation of the thymus with other glands is beyond the scope of this paper. It is interesting in passing, however, to note its rela- tion to the sexual organs. It had long been known by butchers that the thymus of castrated cattle was larger than that of bulls. Henderson, at the request of Noel Paton, investigated this point. He found that the thymus of the castrated was nearly twice the size of that in uncastrated, and that its atrophy is delayed.

Symptoms and T'reatment. In 1829 Kopp first described a disturbance of respiration due to persistent or enlarged thymus, which he ascribed to pressure upon the trachea. In 1858, however, Friedleben ${ }^{6}$ stated very emphatically that "enlargement of the thymus is not to be considered as a cause of death." This pronouncement by so eminent an apthority undoubtedly set back progress along this line for many years. In 1888, Grawitz reported two sudden deaths in infants, in which the autopsy disclosed an enlarged thymus. This was closely followed in 1890 by Paltauf' ${ }^{7}$ description of the so-called "status lymphaticus," in which, he believed, though the thymus was enlarged in every case, the enlargement was not the cause of death. Hedinger, ${ }^{8}$ however, in 18 autopsies on cases of thymus death, proved pressure in each case. Beneke ${ }^{0}$ showed that the simple throwing back of the head was sufficient to produce pressure, and Jackson, ${ }^{10}$ in 1907, demonstrated by bronchoscopy, direct pressure upon the trachea in a case of enlarged thymus without any accompanying signs of status lymphaticus. At about the same time Rehn, ${ }^{11}$ by excising a piece of the gland and thus relieving the symptoms, proved them to originate from pressure. Not only may the thymus compress the right or left auricle, but by displacing the blood vessels cause irritation of the inferior laryngeal nerve, and thus cause spasm of the glottis, according to Crotti. ${ }^{12}$ This, accordingly, is the view held by most observers today, despite some arguments for the internal secretion theory.

As seen in man, the pathology is practically always that of a simple hyperplasia. New growths occasionally occur, and congenital syphilis is believed by some to have a part.

The characteristic clinical syndrome of this affection is the so-called "thymic asthma,"-sudden severe attacks of dyspnea, stridor and suffocation. Most common in early infancy, it may occur as a sudden complication in other diseases in older children, in whom it may be a cause of sudden death. This latter condition is termed by D'Oelsnitz, ${ }^{13}$ who first described it, as "]atent hypertrophy of the thymus." Holt ${ }^{14}$ recog. nizes thymus hypertrophy as a possille eause of convulsions in infants, without other signs. The dyspnea is of the expiratory type,-the stridor inspiratory. In many cases diagnosis can be made by percussion, the thymus presenting a roughly shield-shaped area of dullness, broadest above, and merging into the heart dullness below by an isthmus which varies in length and breadth according to the degree of hypertrophy. 
Bulging of the upper part of the chest has also been observed.

Sylvester, ${ }^{15}$ of Boston, makes a distinction between the symptoms of cyanosis, stridor, and slow, labored breathing, and those of breathing of the asthmatic type, characterized by fairly easy inspiration and long, difficult expiration accompanied by râles. The first syndrome he ascribes to pressure, the latter to hypersecretion of the thymus.

In differential diagnosis, incoördination of the vocal cords, malformation of the larynx, and when occurring some time after birth, enlarged bronchial glands, adenoids, and swallowed foreign bodies must be ruled out.

The diagnosis is usually best made from a good Roentgenogram, when the enlarged gland appears as a broadening of the upper mediastinal shadow to right or left, or both. An enlargement to the right may be due to other causes, but with broadening to the left, the diagnosis is reasonably certain.

Too much dependence, however, must not be placed on the x-ray. The "critical space of Grawitz," as that writer named the superior opening of the thorax, is in young infants less than $2 \mathrm{~cm}$. in diameter, and a very slight antero-posterior cnlargement of the gland in this region is sufficient to produce pressure on the trachea, esophagus, and all other structures which pass this point. Diagnosis in such cases, accordingly, must rest on the clinical symptoms.

The first method of treatment proposed was, naturally, surgical removal. The work of Rehn has already been mentioned. Later, resection of the manubrium was tried, and finally thymectomy. Andrews, ${ }^{16}$ writing in 1913, claimed that simple ablation of the gland could be done with. out much risk. Parker's ${ }^{17}$ report of 50 cases, however, published about the same time, showed a mortality of $331-3 \%$. It is interesting to note the change of heart shown by Veau, ${ }^{18}$ a French surgeon, who was a pioneer in the work and to whom were credited 11 of Parker's 50 casts. In 1912 he reported to the Paris Pediatric Socicty two cases of his own treated by the Roentgen method, and stated, "for over a year I have not done a thymectomy, and have not yet been disappointed in radiotherapy." It will presently be shown that the latter method obviates even the slight risk claimed by Andrews, and from a practical standpoint it must be admitted that consent to a non-surgical method is much more easily secured than for surgery on patients of such tender age.

The high percentage of mortality from surgical intervention, together with the known success of the Roentgen ray in destroying other structures of a lymphatic nature, induced a trial of this agent. The first case reported was that of Friedlander and Crane, ${ }^{10}$ at Cincinnati in 1904. In 1907 Rudberg, ${ }^{20}$ by experiments on animals, showed that it was possible to induce all grades of shrinking in the gland, up to the point of complete fibrosis and destruction of all gland tissue, by action of the ray. Sidney Lange, ${ }^{21}$ of Cincinnati, working independently at about the same time, confirmed these results, showed that it was possible to vary the rate of the atrophy by varying the intervals and intensity of the irradiation, and in 1910 ho reported to the American Roentgen Ray Society a series of five cases successfully treated. Further confirmation was given the method by the report of Ribideau' ${ }^{22}$ ease, in which, after intensive irradiation had caused the disappearance of the dyspneic symptoms within a few days. The child died later of measles; the autopsy showed fibrous atrophy of the thymus gland. Lange's last report, presented before the Roentgen Ray Society in 1913, ${ }^{22}$ included 30 cases from his own and other clinics, in every one of which the application of the ray was followed by prompt and complete recovery. Among later case reports may be mentioned those of Sylvester ${ }^{15}$ and of MForgan and Dachtler. ${ }^{23}$

The contrast of these excellent records with the one-third mortality of thymectomy would seem to be sufficient argument for Roentgentherapy, but there is still further evidence to be cited. The objections raised by the advocates of surgical treatment are, first, that the slow action. of the ray renders it unsuited for urgent cases, and second, that the gland tends to regenerate rapidly after involution produced by the ray. Rudberg, however, in his experiments already cited, found involution beginning $31 / 2$ hours after the first exposure. Lange, in at least one urgent case, was able to bring about a symptomatic cure by one massive treatment. His patient was in such condition that tracheotomy had been done prior to its admission into the hospital. He does not claim that the thymus under these circumstances has undergone complete involution, but simply that its size and function have been decreased sufficiently to tide the patient over a dangerous period. In the milder cases one massive application has produced a symptomatic cure.

The second objection, that of tendency to regeneration, can with justice be brought against surgical treatment as well. The serious results of complete thymectomy in animals have been chronicled. Parker, the advocate of surgical treatment already mentioned, gives as his opinion that the removal of small bits of the gland directly concerned in the production of pressure is as effective as that of larger portions. He believes further that complete thymectomy is practically impossible in the human being. In one of his own cases, regeneration to normal size followed a fairly complete thymectomy. Klose and Vogt's experiments on dogs showed complete thymectomy to be necessary to produce symptoms of thymus deprivation, and that if part of the gland were left, it promptly returned to its former size. The two methods of treatment thus stand on the same footing with re- 
spect to regeneration, but if this occurs after Roentgentherapy it can readily be controlled by repetition of the treatment.

The possibilities of this method of treatment will doubtless be found to increase as our experience with it grows. It is believed by many that there is a connection between enlargement of the thymus, adenoids, and hypertrophied tonsils, and the thymus condition may well be as common as the other two. The irradiation of all suspicious cases might save them from death under an anesthetic or intereurrent infection oceurring before the third year, at which time spontaneous relief usually occurs. Even the acute symptoms may not be manifest in every case. The thymus is always a potential source of danger and possible cause of death.

The interrelation of enlarged thymus and hyperthyroidism is now pretty generally recognized. Autopsies on cases of Graves' disease show enlarged thymus in $75 \%$, and in the cases dying after operation the proportion was found at Munich to be even higher. The exact rôle played by the thymus, whether a casual factor or a direct cause of death remains to be worked out. Hector McKenzie, quoted by Parker, found the thymus enlarged in all his cases of Graves' disease that came to autopsy, and suggests that possibly every case in which there is a thymus persisting into adult life is one of potential or latent Graves' disease. For some years the Mayo clinic, among others, has used preoperative irradiation on their cases of exophthalmic goitre, and it may well be that the beneficial effects have been due to the action of the rays on the thymus instead of the thyroid. As an example of thymus hypertrophy in adult life, Lange quotes the case of a woman of 35 , suffering for one year with palpitation and choking sensations, increasing so that swallowing and breathing became difficult. X-ray examination disclosed what was believed to be an enlarged thymus. One massive treatment gave relief, after which improvement was progressive.

The excellent article of Lange has already been liberally drawn upon in the preparation of this paper. His deductions, however, are so well-phrased that I shall venture to quote them in conclusion:

1. Roentgen irradiation of the thymus produces artificial involution of the gland.

2. X-ray therapy is the method of choice in cases of enlarged thymus in children, whether the symptoms be mild or urgent.

3. Urgent cases should receive repeated massive doses.

4. Recurrences due to regeneration of the gland are to be watched for and controlled by further treatment.

5. Children whose physical or mental development is retarded should, if suspicion is directed toward the thymus, receive tentative $x$-ray treatment, even though a positive diagnosis cannot be established.

6. X-ray therapy as a precautionary measure, or preoperative treatment may enable children of the so-called lymphatic type to withstand intercurrent disense or anestheties, which would otherwise prove fatal.

7. Pre-operative exposure of older children and adults, where there is a suspicion of enlarged thymus, might lessen operative mortality.

8. Routine pre-operative x-ray treatment in cases of hyperthyroidism should be resorted to with a view to lessening operative mortality.

9. X-ray exposure of the thymus gland has been proven harmless, whether in normal or abnormal individuals. A therapeutic test with the $x$-ray is, therefore, always permissible.

\section{REPORT OF PEIR-ONAL CASES.}

Case 1. Boy aged ten weeks. Born after normal labor. When ten days old had sudden attack of dypsnea and collapse, which recurred frequently at intervals of a few days, and rendered the constant presence of two nurses necessary. X-ray examination was inconclusive, but on the basis of clinical symptoms Roentgentherapy was decided on. Five treatments were given at five-day intervals. After the first exposure the suffocative attacks ceased and the child began to develop normally. $\Lambda$ t the age of eight months adenoids were removed under light anesthesia, with complete success.

Case 2. Boy aged 20 months. Weight 'at birth, $71 / 4 \mathrm{lbs}$, at 1 year $241 / 2 \mathrm{lbs}$. The nurse who attended his mother at birth states that for the first few days the child was constantly troubled with accumulation of mucus in the throat, requiring much attention. Thereafter ho developed rapidly and had no sickness during first year. During the fall of 1914 he began to catch cold easily and often. This was noticeable as he had been so free from colds during his first year. He developed a spasmodic cough. so that whooping cough was at first suspected. This cough and a wheezy asthmatic breathing continued throughout the winter. At times it seemed to be controlled by full doses of belladonna. In January, 1915, adenoids were removed, without marked benefit. He was then sent to Atlantic City to see if the change of air would help him. It did not. Dr. Hollinghead, of Philadelphia, then suggested a Roentgenogram.

X-ray examination by Dr. W. S. Newcomet of Philadelphia revealed enlarged thymus, also marked enlargement of right pulmonary hilus shadow. Von Pirquet test positive. $X$-ray treatment was ineffective until the dosage was increased, when improvement began. A Roentgenogram taken after three months shows marked diminution of thymus shadow. This child's general condition continues to improve, and he has no severe suffocative attacks. At times, however, stridor and dyspnea reappear in some degree, and an occasional treatment is given. In a personal conversation with the writer, Dr. Newcomet stated that he considered this case to be one of the so-called "glandular babies," and advised vigorous raying over large areas of the chest. This advice is now being followed. 
Case 3. This case is reported for what it is subject was purposely omitted. It should be worth; the striking result being sufficient justifica- begun lightly and increased if results do not tion. The patient was a boy aged three days. Born follow. The writer's average has been from two after normal labor, he had a violent convulsion when only a few minutes old, and these continued at the rate of five or six daily. Prominence of the upper portion of the chest suggested the possibility of enlarged thymus as the causative agent. The child was brought for examination at 7.30 p.m., having had a convulsion at 5 . It was very weak and ap- of reporting the cases here cited.

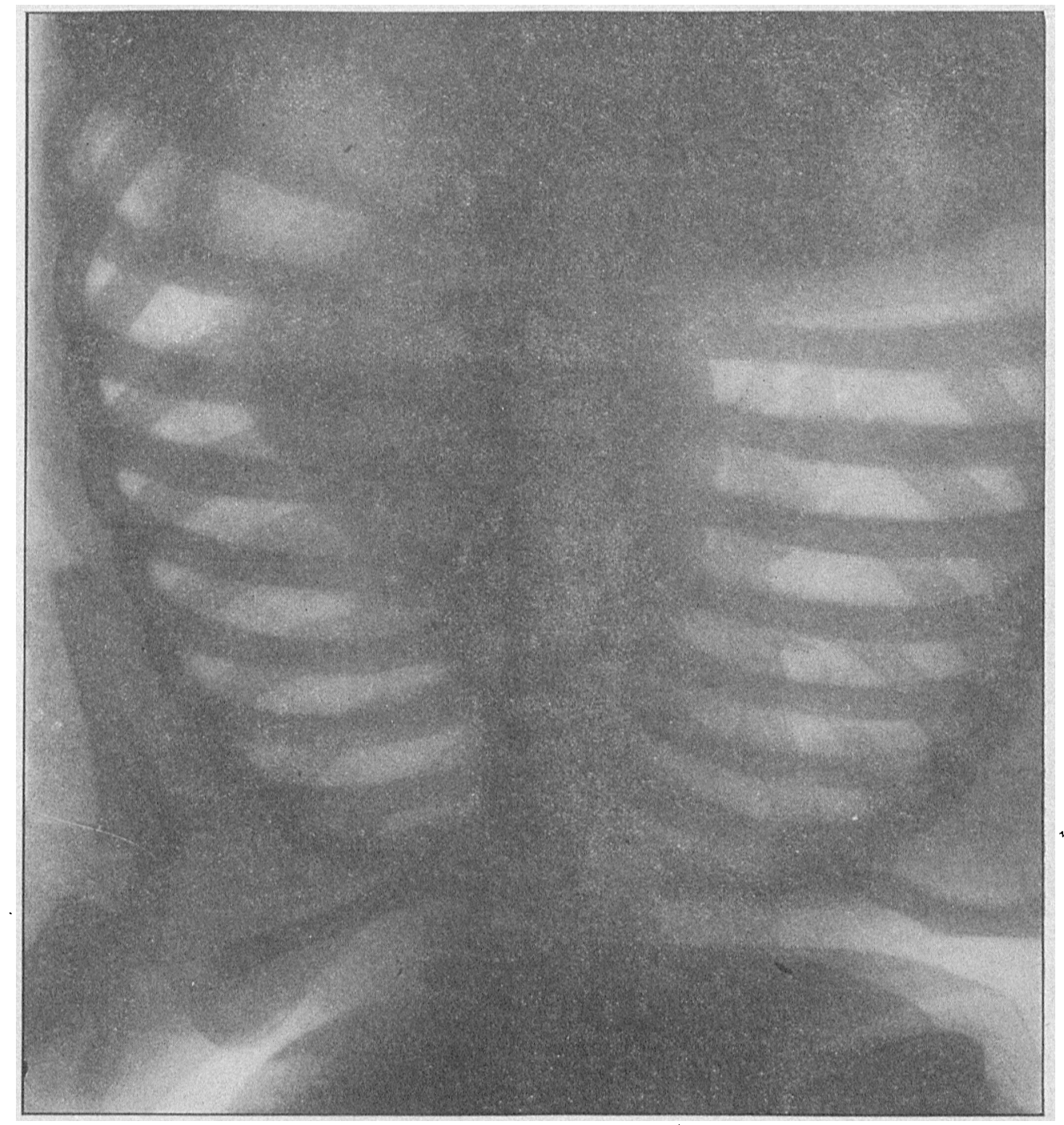

Case IJ.-Dr. Newcomet's phate before treatment, shewing enlargement of thymus and hilus shadows.

peared to be nearly in extremis. Roentgenograms, rather hastily taken on account of the child's condition, showed a suspicious shadow in the upper mediastinal region. $A$ treatment as vigorous as seemed safe was at once given. The child rosted well that night; at $5 \mathrm{a}$.m. the next day had a little twitching of the eyelids but no convulsion. Began to nurse normally. Three treatments were given at three-day intervals. No more convulsions occurred and the child at once began to develop in a normal way, which improvement has continued to the present, -6 weeks after the last treatment.

Dosage varies so much that discussion of the to three minutes with a hard ray, filtered thru aluminum.

'The writer's thanks are due to Dr. Maynard Ladd of Boston, Drs. G. M. Albee, M. Lincoln and $A$. W. Marsh of Worcester for the privilege 
find the general condition behind it if we are; and a sensitiveness of the respiratory mucous to get anywhere. In looking around, one of the membranes. Many other symptoms are often general conditions which we run across is the present, such as an intermittent fever, chills, so-called lymphatic constitution and this is what perspiration, adenoids and swelling of the tonI first want to discuss in its relation to asthma.

Three states of childhood are spoken of to- anemia, pseudo-hypertrophy of the heart with gether, namely, the lymphatic constitution, palpitation or arrythmic pulse; a tender skin, neuro-arthritism and exudative $d i$ athes is. urticaria, intertrigo, crusts on the face and scalp, Whether they are entirely different conditions “czema; coryza, hay fever, laryngitis, diffuse or different manifestations depending on the pre-/ tracheo-bronchitis, bronchiolitis and bronchial

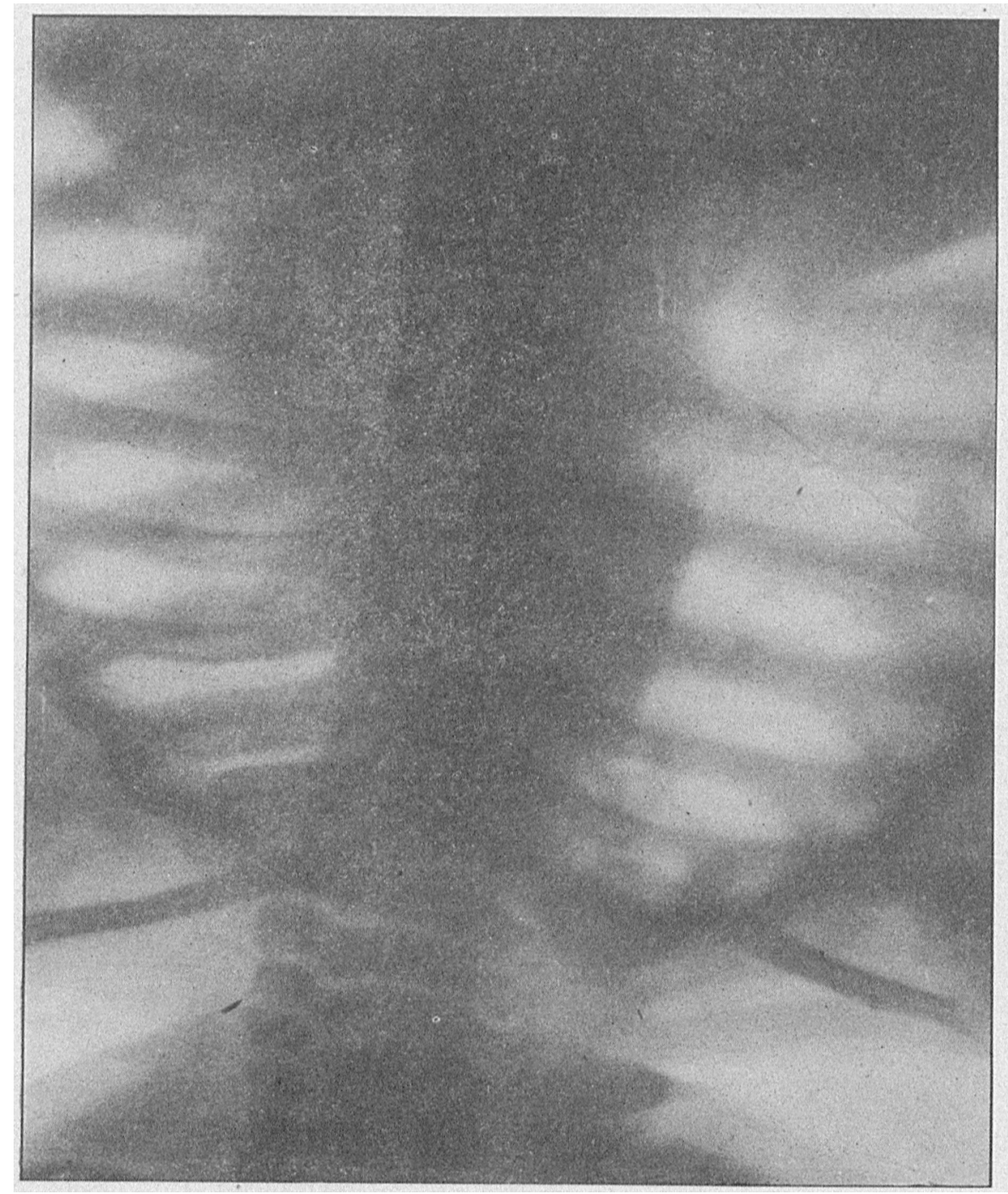

CAse II.-Aftor trentment. Showing dimimution in thymus shadow:

dominating symptoms of the same condition is asthma; a coated tongue, geographical tongue, not clear, but probably if the latter is not true habitual constipation with muco-membranous enthen at least they stand in close relation to each teritis and eyclic vomiting. This is only a parother. We differentiate the pastous or lymphat- tial list of the symptoms and as these symptoms is anemic habitus with hypoplasia of the lym- go with other conditions, it shows the complicaphatic system and a stupid temperament; the tions and uncertainty of their relations.

erethic or neuro-arthritic habitus, restless and On one extreme we have the predominating irritable with tender skin, and rather precocious lymphatic type, and it is probable that so-called intelligence, and the plethoric obese habitus, lymphatism or status thymico-lymphaticus with babies of tremendous adipose tissue. The gener- hypertrophied lymphoid tissue, enlarged spleen al signs and symptoms are a hyperplasia of the and thymus, with tendency to sudden death is lymphatic system, a sensitiveness of the skin. the same condition. If to this we add one of 
the prominent symptoms of the exudative diathesis, namely asthma, then we may find a condition closely related to the so-called thymic asthma just brought to your attention. Second is the prominent group with eczema predominating, and third the group with asthma. It may not be necessary that the connecting link between these be a demonstrable pathological lesion of the lymphatic tissue. There may be a biochemical relation. Pfaundler stated several years ago that the diet had a marked effect on causing these conditions, while digestive disturbances are common. 'To quote him, "Is it not possible that under certain conditions (an unfavorable predisposition as to the function of intestinal and cellular digestion) foodstuffs digested into the gastro-intestinal tract might act in the body like an antigen; if this should be the case, then it would be quite natural to assume that the lymphatic diathesis represents a kind of food allergia (food anaphylaxis)."

Schloss in 1912 showed that egg poisoning in children is a form of anaphylaxis. It is well known that eczema is made worse by excess of fats and carbohydrates, but some recent work goes to show that proteids often are an exciting cause. To come directly now to the question of child asthma, it has just been shown that certain proteids may bring on in a child so predisposed typical attacks of bronchial asthma. It seems to me that this subject of proteid anaphylaxis or sensitiveness to proteids is being widely cpened up, and that we are at a point of view of great importance. Whether there is any relation between lymphatism and proteid anaphylaxis is a very open question. Talbot has studied infants in relation to proteid anaphylaxis to asthma. The sensitization apparently takes place either by the unchanged proteid passing directly into the blood through the intestinal mucous membrane in the earliest weeks of life, or through the injured intestinal mucous membrane in later infancy during some digestive upset as diarrhoea. There may be also an inherited sensitiveness. The infants are tested by scarifying the skin and rubbing in the suspected proteid. Several foods may be tested at once on as many scarifications. Egg white, various kinds of meats, beef juice, milk for the casein, various grains such as barley and oat meal for the gluten, etc., are used. Within 15 minutes a small wheal or an erythema arises where the causative proteid was innoculated. Talbot has found that various proteids are the factors in many cases of child asthma, egg being the commonest cause. After the egg is found to be a cause, the asthma ceases on withdrawing the egg from the diet. This, of course, is a most inconvenient procedure, so he has attempted to accustom the child to egg by starting with one milligram doses of eg.g albumen in capsule by mouth, with increasing amounts, and he has met with success which is, however, if not complete, encouraging.

My personal experience is rather limited. One child with an idiosyncracy to egg, manifested by urticaria and eczema, had a typical attack of bronchial asthma. Attempts to immunize her brought on oedema with the third milligram dose of egg albumen. Another older boy had partial relief from his asthma when beef, to which he reacted, was withdrawn from his diet. The most striking case was a child of a year of age. At nine months she had had a good deal of mucus in her movements so at this time she may have become sensitized. About every three weeks she would have an unaccountable attack of mucous colitis and either asthmatic bronchitis or asthma. It took several attacks before we realized the attacks were true asthma and not primarily recurrent infections of the bronchial mucous membranes. Attempts at regulation of the diet were unavailing, for apparently what agreed with her at one time did not at another. Finally, by testing the skin with all foods she was taking that contained proteid, it was found that her troubles were due to beef juice. After withdrawal of this she had practically no more asthma, although she had a few more attacks of: mucous colitis due to an apparent sensitiveness to milk proteid. But after her diet became more varied she showed marked improvement in this condition also. Here it seemed that it took the accumulation of two or three weeks of daily portions of beef juice before sufficient poison was at hand to bring on an attack, a condition somewhat different from the egg cases where perhaps one morsel of food containing egg may bripr on asthma.

Noel Paton: Regulators of Metabolism, Edinburgh, 1012 1010.

lose and Vogt: Klin. u. Biol. der Thymusdrise, Tubingen,

Svehla: Minch. med. Woch., 1900, quoted by Falta, Ductless andular Diseases, N. Y., 1015, Chap. V, p. 225.

Popper: Quoted by Falta, loo. cit.

- Noel Paton: Loc. cit.

Friedleben: Physiol. der Thymus, Frankfort, 1858.

Prltauf: Wien. klin. Woch., No. 46, 1890.

Hedinger: Jahrbuch fir kinderheil., 1906, 63.

10 Beneke: Berl. klin. Woch., 1894, No. 9.

11 Jackson: Jour. A. M. A.. May 25, 1007.

12 Crotti: Jour. A. M. A., Jan., 11 and Feb. 22, 1913

18 D'Oelsnitz: Quoted by Iange, q. v.

14 Holt: Diseases of Children.

15 Sylvester: BOBTON MED. AND SURa. Jour., April 2, 1014.

10 Andrews: Keen's Surgery, Vol. 6, p. 327 .

17 Parker: Amer. Jour. Dis. Chil., Feb., 1913

Veau: Quoted by Lange, q. v.

Friedlander: Arch. Pediatries, July, 1907.

Rudbere: Arch. fir Anat., 1907.

IAnge: Amer. Jour. Roentgenologv, Dec. 1913.

Sor. Med. de îp. de Paris, 1012

Morgan and Dachtler: Sure., Gyn. and Obst., Dec., 1014, 781.

\section{GUILLAUME DUPUYTREN，1777-1835:}

By Wimlam Pearce Coues, M.D., Boston.

IT has been said with truth, that if a physician in America wished to do research work on some subject he was especially interested in, that he could not go far in his researches without finding that it had all been done before by a German. I would change the saying some- 